\title{
Cocoa Bean Hulls: Effect on Nutritional Quality, Texture and Sensory Properties of Pound Cake
}

\author{
Elif Öztürk ${ }^{1, a}$, Gülden Ova ${ }^{1, b, *}$ \\ ${ }^{I}$ Department of Food Engineering, Faculty of Engineering, Ege University, 35100 İzmir, Turkey
}

*Corresponding author

\begin{tabular}{l|l}
\hline A R T I C L E I N F O & A B S T R A C T \\
\hline Research Article & $\begin{array}{l}\text { In this study, wheat flour was substituted with the following ratios of the raw (RCBH) and leached } \\
(\mathrm{LCBH}) \text { cocoa bean hull }(\mathrm{CBH}) \text { in pound cakes (PC) (CBH/wheat flour ratios: 20/80 (20\%), 30/70 } \\
(30 \%) \text { and } 40 / 60(40 \%)), \text { respectively. The proximate composition and the content of bioactive } \\
\text { compounds in the cake samples for each weight ratio of RCBH and LCBH and in the hulls were } \\
\text { evaluated. Fiber, ash, total antioxidant activity (TAA) and total phenolic compound (TPC) contents } \\
\text { increased with the CBH content in the cakes. No significant difference was found in the specific } \\
\text { volume among the cake samples. Based on the results of the textural analysis, all cake samples } \\
\text { showed higher hardness, lower springiness and cohesiveness than those of the control cake. } \\
\text { Regarding to the color of the crumb and crust, the 40\% LCBH and RCBH cakes presented the lowest } \\
\text { Accepted : }: 11 / 12 / 2019 \\
L^{*}, a^{*} \text { and } b^{*} \text { values. According to the Principal Component Analysis (PCA), it was observed that } \\
\text { the properties with respect to the cell uniformity, adhesiveness, sweetness, oiliness and humidity of } \\
\text { the 20LCBH and 20RCBH cakes can be distinguished clearly from the other flour substituted cakes. }\end{array}$ \\
$\begin{array}{l}\text { Keywords: } \\
\text { Cocoa bean hulls } \\
\text { Flour substituted cakes } \\
\text { Functional foods }\end{array}$ &
\end{tabular}

nal foods

Texture

Principal component analysis

elifozturk.2407@gmail.com

\section{Introduction}

Recently, food by-products generated during oilseed processing have been searched for their nutrient and functional contents in order to modify the characteristics of the present foodstuffs. During the extraction of the oil from plant seeds in food industry, a considerable amount of the hulls obtained as by product (Johnson, 1970). A majority of them are discarded; a few amounts can be utilized as raw materials in fertilizer, packaging material, animal feeds and aromatic substances (Arlorio et al., 2005; Bruna et al., 2009). The previous studies have revealed that bioaccessibility and bioavailability of nutshells based on various effects on human health such as antioxidative, antiinflammatory, prebiotic, chemically protective properties and hypocholesterolemia effect which result from phenolic compounds found in nutshells (Chang et al., 2016). In another study, the antioxidant activities of the oilseed hulls were associated with the presence of phytochemicals which provide protective effects against free radicals. Moreover, plant based chemicals includes anticarcinogenic, anti-mutagenic, anti-proliferative effects
(Alasalvar and Shahidi, 2008). Cocoa bean hulls (CBH), regarded as the waste products in cocoa and chocolate industry are composed of approximately $12-15 \%$ of cocoa bean (Kopp et al., 2011). CBH is the primary by-products of cocoa, which exhibit high content of polyphenols. They contain some phenolic compounds in significant amounts and could be used as a food ingredient for the improvement of functional food qualities owing to their contribution the total antioxidant activity (TAA) (Martínez et al., 2012). There is an increasing trend to evaluate $\mathrm{CBH}$ in functional foods because of antioxidant and antiradical properties of the polyphenolic constituents (Bruna et al., 2009). Furthermore, it was reported that cocoa contains the most alkaloid theobromine and caffeine (Timbie et al., 1978; Pritchard, 1991)

Studies in the past evaluated the effects of oilseed hulls and nutshells used in various baking products in order to improve the chemical, textural and sensory properties (Hao and Beta, 2012; Pourfarzad et al., 2013; Dall'Asta et al., 2013). Peanut skin added to cookies increased their total 
phenolic compound (TPC) and gave rise to the improvement of their sensorial properties (Camargo et al., 2014). Flaxseed hulls have been used in bread as well. The $\mathrm{TPC}$, free radical scavenging activity, reducing power properties increased due to the fortification by flaxseed hull. Bread samples were also evaluated for physical and textural properties in order to determine the optimal formulations (Sęczyk et al., 2017).

Investigations of $\mathrm{CBH}$ in food formulations are limited. Martinez-Cervera et al. (2011) used soluble cocoa fiber produced from $\mathrm{CBH}$ the production of chocolate muffins with the different amounts as a fat replacer. The results issued that soluble cocoa fiber could be used as a fat substitute in chocolate muffin making.

In this study it was aimed to evaluate the use of $\mathrm{CBH}$ as a by-product of cocoa bean processing in order to produce flour substituted cakes (FSC) enriched with fiber and bioactive components. For this purpose the effects of substitution with the raw cocoa bean hull ( $\mathrm{RCBH})$ and leached cocoa bean hull ( $\mathrm{LCBH})$ on the final product were also formulated. The quality and sensory properties of the novel foods fortified with the RCBH and $\mathrm{LCBH}$ were compared.

\section{Materials and Methods}

\section{RCBH (Raw Cocoa Bean Hull)}

The cocoa bean hull to be used in the research were obtained from Ülker Çikolata Sanayi A.Ş. They were ground in a hammer mill grinder (Brook Crompton Controls, Wakefield, England) and sieved by 60 -mesh to obtain a particle size smaller than $283 \mu \mathrm{m}$. In other words, the ground and sieved cocoa bean hulls were used as the untreated dietary fiber. They are also called as RCBH.

\section{LCBH (Leached Cocoa Bean Hull)}

The ground and sieved RCBH called as LCBH were treated with the hot water as described by Garcia-Serna et al. (2014). For this purpose, $3.3 \mathrm{~g}$ of $\mathrm{RCBH}$ were treated with $100 \mathrm{ml}$ of boiling water for $10 \mathrm{~min}$ (Garcia-Serna et al., 2014). The solid residue from the extraction process was recovered by the filtration using a filter paper. Following a drying process at room temperature for 24 hours, the residue was exposed to a further drying in an oven at $60 \pm 2{ }^{\circ} \mathrm{C}$ for 8 -h and also was sieved to a particle size smaller than $283 \mu \mathrm{m}$, respectively.

\section{Cake Formulations}

The cake formulations were prepared using the following ingredients: $26.14 \%$ wheat flour, $26.14 \%$ sugar, $12.03 \%$ sunflower oil, $21.18 \%$ egg, $13.07 \%$ whole milk, $0.39 \%$ salt, $1.05 \%$ baking powder for control cake (Martínez-Cervera et al., 2011; Kocer et al., 2007). The ground and sieved powder of the RCBH and LCBH was added into the cakes at three different weight ratios $(20 \%$, $30 \%$ and $40 \%$; w/w) by replacing equal weight ratios of wheat flour of the cake mixture. Relying on their weight ratios in the substitution, the cakes fortified by the RCBH were referred as $20 \mathrm{RCBH}, 30 \mathrm{RCBH}, 40 \mathrm{RCBH}$. The same nomenclature was also used for the samples enriched with the LCBH. The batter was weighed $(600 \mathrm{~g})$ into the Teflon cake mold $(31 \times 12 \times 7 \mathrm{~cm})$ and baked in a preheated oven (Arçelik SUF4000 MEB, İstanbul, Turkey) at $170^{\circ} \mathrm{C}$ for 55 min. The cakes were milled to a powdered form using a coffee grinder and their methanolic extracts were stored at $-18^{\circ} \mathrm{C}$ in airtight vials.

\section{Proximate Composition of the $\mathrm{CBH}$ and Cake Samples}

The moisture, ash, fat, protein, and crude fiber contents of the RCBH and LCBH were determined by AOAC methods: 925.10, 942.05, 963.15, 968.06, and 962.09, respectively (AOAC, 2007). The moisture of the cake samples was measured based on the Method 44-40 (AACC, 2000). The ash, fat, protein and crude fiber of the cakes and $\mathrm{CBH}$ were also determined and expressed on the dry basis.

\section{Physicochemical Composition of $\mathrm{CBH}$}

The water retention capacity (WRC) of the RCBH and LCBH were determined by mixing $2,5 \mathrm{~g}$ of sample with 30 $\mathrm{ml}$ distilled water. The mixtures were vortexed for $1 \mathrm{~min}$ and then centrifuged at $5000 \mathrm{rpm}$ for $20 \mathrm{~min}$, and the volume of supernatant was calculated (Yang et al., 2014). The water solubility index (WSI) of the RCBH and LCBH were calculated by dried supernatant at $40^{\circ} \mathrm{C}$ for 12 hours based on moisture loss in supernatant (Yang et al., 2014).

\section{Bioactive Compound Composition of the $\mathrm{CBH}$ and Cake Samples}

Two grams of the $\mathrm{CBH}$ powder was weighed, and 40 $\mathrm{ml}$ of $80 \%$ methanol was added. The solution was shaken at $142 \mathrm{rpm}$ for 2 hours via DAIHAN Wise Shake SHO Digital Orbital Shaker, respectively. The mixture was centrifuged (Mistral 1000) at $4500 \mathrm{rpm}$ for $15 \mathrm{~min}$. The supernatant was transferred to a $50 \mathrm{ml}$ volumetric flask, and completed with $80 \%$ methanol solution. The cake samples were grinded by the coffee mill (Sinbo SCM2910) and defatted by the treatment with the chloroform:petroleum ether (v/v, 50:50) solution. The defatted cake samples were extracted by the same methods used for the CBH powder extraction (Skerget et al., 2005; Balestra et al., 2011). Afterwards, the $\mathrm{CBH}$ and cake extracts were analysed for the TPC, total flavonoid content (TFC) and TAA.

The TPC of all samples was determined using the Folin Ciocalteu method described by Heimler et al. (2005). The absorbance was measured at $765 \mathrm{~nm}$ using a spectrophotometer. The results were expressed as $\mathrm{g}$ of gallic acid equivalents (GAE) /100 g on dry matter (DM).

The TAA was determined according to Saija et al. (1998) and Rapisarda et al. (1999). The absorbance was measured at $517 \mathrm{~nm}$. The results were expressed as $\mu \mathrm{mol}$ Trolox/g on DM.

The caffeine and theobromine contents of the RCBH and $\mathrm{LCBH}$ powder were measured according to the AOAC method 980.14 (AOAC, 2007). The HPLC-DAD was performed at $280 \mathrm{~nm}$. The results were expressed as $\mathrm{g} / 100$ g on DM.

\section{Physical Composition of Cake Samples}

The baking loss was calculated as the ratio of the weight of batter before baking to the weight of the cake after baking (Martínez-Cervera et al., 2011). The specific volume was measured using rapeseed displacement Method 10.05 (AACC, 2000) and it was calculated as the ratio of the cake's volume to its weight. 


\section{Texture and Colour Determination}

The texture profile analyses (TPA) of the cakes were measured using a TA.XT.plus Texture Analyser (Stable Microsystems, Godalming, UK) equipped with a load cell of $5 \mathrm{~kg}$.

A double compression test was carried out to a height of $1.25 \mathrm{~cm}$ (40\% compression) using a cylindrical aluminium probe (36 mm diameter) at a speed of $1 \mathrm{~mm} / \mathrm{s}$ with a waiting time of $5 \mathrm{~s}$ between the two cycles. The cake crumb hardness $(\mathrm{CCH})$ was determined by the AACC method 74.09 (AACC, 2000). The springiness, cohesiveness and chewiness values were calculated from the TPA graph. Cake loaves were cut into $25 \mathrm{~mm}$ thick slices from the centre for a standard texture profile analysis. Duplicate analysis was also made.

The colour of the cake's crust (CR) and crumb (CB) was measured using a Minolta colorimeter (CR-400, Konica Minolta Sensing, Inc., Osaka, Japan). It was expressed with $L^{*}$ (black $=0$, white $\left.=100\right), a^{*}$ (redness $>0$, greenness $<0$ ), $b^{*}$ (yellowness $>0$ blueness $<0$ ) values (Chen et al., 2010). The colour measurements of the CR were made on the five different pre-selected locations for each loaf while the colour of the $\mathrm{CB}$ was measured on five central slices of each sample for the cakes (MartínezCervera et al., 2011).

\section{Sensory Analysis of FSC}

In the preliminary studies, $10 \%, 20 \%, 30 \%, 40 \%, 50 \%$ and $60 \%$ of the CBH as FSC samples were evaluated by the ranking test in order to select the most appropriate ratio of the hulls to be used in the cake formulations. The cakes were evaluated according to the colour, texture (hand and mouth), taste and overall acceptance criteria. For the statistical evaluation of the results obtained in FSC, the acceptable score was determined between 25 and 48 in the $5 \%$ confidence interval corresponding to 6 treatments and 11 replicates (Altuğ and Elmacı, 2015).

The descriptive sensory analysis was applied to the FSC. Six trained assessors were used in the sensory analysis. During the training sessions, the appearance, texture and flavour characteristics of the cakes were evaluated using a $7 \mathrm{~cm}$ unstructured line scale $(0$ - none and 10 extreme). The sensory analysis was performed twice at room temperature individually. Each cake formulation was prepared twice and evaluated at two separate sessions within the day. The assessors received only a single cake formulation at a session. The definitions made for the evaluations of the sensory properties are shown on Table 1.

\section{Statistical Analysis}

The RCBH and LCBH analyses have been conducted in triplicate, whereas the cake formulations were prepared in duplicate and the analyses were performed in duplicate. IBM SPSS 20 software was used to evaluate the results. The results for the RCBH and $\mathrm{LCBH}$ were determined by the independent $\mathrm{t}$-test. The physical, chemical and sensory quality of cake formulations replaced by RCBH and LCBH at different percentages $(0,20,30$ and $40 \%)$ were evaluated with the analysis of variance (ANOVA), respectively. Significant differences among groups at the level of 0.05 were determined by Duncan's multiple range tests. The results were evaluated at a $95 \%$ confidence interval. Moreover, the differences in sensory characteristics among the cakes were tested by the PCA using XLSTAT version 2013.1.

Table 1. Descriptive terms and definitions used in sensory analysis of cakes by trained panelists

\begin{tabular}{l|l}
\hline Terms & Definitions \\
\hline Appearance & Typical cocoa colour in cake crumb \\
$\begin{array}{l}\text { Crumb browness } \\
\text { Cell uniformity }\end{array}$ & $\begin{array}{l}\text { Amount and size of gas cells, homogeneity of air bubbles } \\
\text { Texture (hand) }\end{array}$ \\
$\begin{array}{l}\text { Adhesiveness } \\
\text { Texture (mouth) }\end{array}$ & Speed of crumb shape recovery when pressure applied by a finger and then is removed \\
Hardness (mouth) & Resistance to chewing and difficulty in swallowing \\
Oiliness & Oiliness in the mouth \\
Moistness & Cake moisture in the mouth \\
Fibrousness & Residual in the mouth \\
Flavour & Typical cocoa taste intensity \\
Cocoa taste & Bitterness from cocoa \\
Bitterness & Fruity woody odor \\
Odor & Sweetness intensity \\
Sweetness &
\end{tabular}

\section{Results and discussion}

\section{Chemical Properties of the $\mathrm{CBH}$}

Table 2 summarized the proximate composition of the $\mathrm{RCBH}$ and $\mathrm{LCBH}$. The ash and protein content of the LCBH was significantly lower than those of the RCBH $(\mathrm{P}<0.05)$. One might conclude that these chemical properties decreased with the leaching process (LP). In a study related to the $\mathrm{CBH}$ growing in the Cone and Taura regions, the moisture (7.71-7.80 g/100 g), ash (7.35-6.76 g/100 g DM), protein (15.85-15.79 g/100 g DM), fat (2.02$2.05 \mathrm{~g} / 100 \mathrm{~g} \mathrm{DM})$ contents of CBH showed similar results, respectively (Martinez et al., 2012). The crude fiber contents of $\mathrm{CBH}$ were determined as $\% 19.70$ by Altug (1987) which were similar to Table 2 crude fiber value of the RCBH. In another study, fat, protein and fiber content (FPFC) of $\mathrm{CBH}$ were found between $3.1-5.2 \%$; 14.5$21.6 \%$ and 17.4-20.9\%, respectively (Adamafio, 2013). 
The FPFC of the RCBH powder in Table 2 were found in the range of literature data. Arlorio et al. (2005) also found that $\mathrm{CBH}$ contain $68.1 \mathrm{~g} / \mathrm{kg}$ fat, $181.2 \mathrm{~g} / \mathrm{kg}$ protein; $81 \mathrm{~g} / \mathrm{kg}$ ash and $60.6 \mathrm{~g} / \mathrm{kg}$ fiber content (Martinez et al., 2012). WRC of a substance refers to the amount of the insoluble matter in water and the WSI refers to the amount of watersoluble material (Robertson et al., 2000; Yang et al., 2014). Accordingly, the WRC and WSI of RCBH decreased significantly with the LP $(\mathrm{P}<0.05)$. When the WSI of soybean hulls was investigated, results showed similarly with $\mathrm{CBH}$ (Yang et al., 2014). The WSI of the RCBH are five times higher than that of the $\mathrm{LCBH}$, indicating that the
LP removed the water-soluble components. In literature, the WSI of soybean hulls decreased approximately by $500 \%$ by means of the leaching process. The WSI of leached soybean hull powder is less than the WSI of the raw soybean hull powder. By the LP, $57 \%$ of caffeine and $69 \%$ of theobromine were removed from the CBH. When the results are statistically evaluated, it was seen that the $\mathrm{LP}$ applied to the $\mathrm{CBH}$ caused a significant reduction in the amount of caffeine and theobromine $(\mathrm{P}<0.05)$ (Table 2$)$. Altuğ (1987) determined the caffeine and theobromine values of $\mathrm{CBH}$ as $0.80 \%$ and $0.06 \%$.

Table 2. Proximate analysis, physico-chemical properties and bioactive compounds of RCBH and LCBH

\begin{tabular}{|c|c|c|}
\hline & $\mathrm{RCBH}$ & $\mathrm{LCBH}$ \\
\hline Moisture (g/100g ) & $6.36 \pm 0.12^{\mathrm{a}}$ & $9.57 \pm 1.62^{b}$ \\
\hline Ash $(\mathrm{g} / 100 \mathrm{~g} \mathrm{dm} *)$ & $11.42 \pm 1.46^{\mathrm{a}}$ & $5.22 \pm 0.11^{\mathrm{b}}$ \\
\hline Protein $(\mathrm{g} / 100 \mathrm{~g} \mathrm{dm})$ & $16.05 \pm 0.09^{\mathrm{a}}$ & $14.82 \pm 0.27^{\mathrm{b}}$ \\
\hline Fat $(\mathrm{g} / 100 \mathrm{~g} \mathrm{dm})$ & $4.37 \pm 0.38^{\mathrm{a}}$ & $4.70 \pm 0.48^{\mathrm{a}}$ \\
\hline Crude fiber $(\mathrm{g} / 100 \mathrm{~g} \mathrm{dm})$ & $17.66 \pm 0.27^{\mathrm{a}}$ & $18.48 \pm 0.13^{\mathrm{a}}$ \\
\hline Water retention capacity (g water/g dm) & $3.43 \pm 0.16^{\mathrm{a}}$ & $2.31 \pm 0.12^{\mathrm{b}}$ \\
\hline Water retention index $(\%)$ & $20.26 \pm 0.93^{\mathrm{a}}$ & $3.80 \pm 0.37^{\mathrm{b}}$ \\
\hline Total phenolic compounds (mg GAE $\left.{ }^{* *} / 100 \mathrm{~g} \mathrm{dm}\right)$ & $370.97 \pm 0.03^{\mathrm{a}}$ & $39.25 \pm 2.26^{\mathrm{b}}$ \\
\hline Total antioxidant activity ( $\mu \mathrm{mol}$ Troloks/g dm) & $17.27 \pm 0.46^{\mathrm{a}}$ & $2.38 \pm 0.17^{\mathrm{b}}$ \\
\hline Caffeine $(\mathrm{g} / 100 \mathrm{~g} \mathrm{dm})$ & $0.07 \pm 0.00^{\mathrm{a}}$ & $0.03 \pm 0.00^{\mathrm{b}}$ \\
\hline Teobromine (g/100 g dm) & $0.72 \pm 0.72^{\mathrm{a}}$ & $0.22 \pm 0.22^{\mathrm{b}}$ \\
\hline
\end{tabular}

Means \pm standard deviation followed by different letters within a column for each cultivar are significantly different at $\mathrm{P}<0.05$, *dm=dry matter, $* * \mathrm{GAE}=$ gallic acid equivalent

\section{TPC and TAC Values of CBH}

The methanol extracts of RCBH and LCBH were examined for their TPC and TAA (Table 2). The results are evident for a significant decrease in the TPC and TAA values by $\mathrm{LP}(\mathrm{P}<0.05)$. In the literature, the TPC of $\mathrm{CBH}$ grown in Madagascar, Ghana, Venezuela, Ecuador, Trinidad regions was found between 256-406 mg GAE/100 g (Bruna et al., 2009). In the study of Bruna et al. (2009), it was demonstrated that TAA showed a high correlation with polyphenol contents of $\mathrm{CBH}$ and it was reported that $\mathrm{CBH}$ from different geographic origins showed significant difference. In this study, TPC content was also found between the ranges as reported in literature. The related studies pointed out that TPC of cocoa hulls was determined as $18.2 \mathrm{~g}$ Catechin $/ \mathrm{kg}$ (Arlorio et al., 2005). In an another study, the TPC (5.78 g GAE/100 g) and TAA were measured by FRAP $(72.32 \mu \mathrm{mol}$ Trolox/g) and TEAC (7.73 $\mu \mathrm{mol}$ Trolox/g) methods of the fiber-rich $\mathrm{CBH}$ obtained from the cocoa kernel (Lecumberri et al., 2007). In another study, TPC and TAA of $\mathrm{CBH}$ whose regions were Cone and Taura was evaluated. TPC values of the $\mathrm{CBH}$ were found 154.43 and $144.83 \mathrm{mg} \mathrm{GAE} / 100 \mathrm{~g}$ with the methanol: acetone which were higher than the value of the extracts in ethanol ( 80.17 and $82.37 \mathrm{mg} \mathrm{GAE} / 100 \mathrm{~g}$ ), respectively. In the DPPH assay, TAA of hulls were determined in methanol: acetone extracts as 3.81 and 4.05 $\mu \mathrm{M}$ of Trolox/g which were also higher than the values of the ethanolic extracts (1.57 and $1.71 \mu \mathrm{M}$ of Trolox/g) for Cone and Taura respectively. Hence, one might claim the TPC and antioxidant levels of hulls were affected by the regions of cocoa beans and type of solvents used for the extraction. Thus, the difference between the ranges reported in the previous studies might depend on this fact (Martinez et al., 2012). The TAA values were determined by QUENCHER method and also found to be $14.3 \mathrm{mmol}$ Trolox $/ \mathrm{kg}$ in the peanut, $6.5 \mathrm{mmol}$ Trolox $/ \mathrm{kg}$ in the pine nuts, $8.1 \mathrm{mmol}$ Trolox $/ \mathrm{kg}$ in the cashew nuts, $6.0 \mathrm{mmol}$ Trolox $/ \mathrm{kg}$ in the coconut flour, $12.0 \mathrm{mmol}$ Trolox $/ \mathrm{kg}$ in the sesame seeds $/ \mathrm{kg}$ and $6.6 \mathrm{mmol}$ Trolox $/ \mathrm{kg}$ in the pumpkin seeds (Açar et al., 2009). The RCBH given in Table 2 exhibited higher TAA than those of oilseeds and nuts.

\section{Chemical Properties of FSC}

Regarding the chemical composition of the pound cakes (PC), there is a significant difference between the control and $30 \mathrm{RCBH}, 40 \mathrm{RCBH}, 40 \mathrm{LCBH}$ are reported in Table $3(\mathrm{P}<0.05)$. Furthermore, ash and crude fiber content of the cake samples given in Table 3 significantly increased with the addition of $\mathrm{LCBH}$ and $\mathrm{RCBH}(\mathrm{P}<0.05)$. In a study which inspected the muffin samples used as substitutes of Idared apple peel powder as 0\%-32\%, the moisture values $31.39 \%-30.93 \%$ and ash values $1.39 \%-1.54 \%$ were determined (Rupasinghe et al., 2008). Higher moisture and lower ash contents of muffins were obtained compared with this study. Table 3 shows the data for protein contents no significant difference was found among the RCBH and LCBH substituted cakes except from 40LCBH $(\mathrm{P}>0.05)$.

\section{TPC and TAC Values of PC}

The TPC content of the PC increased significantly by the addition of the $\mathrm{CBH}(\mathrm{P}<0.05)$. The TPC content of the cakes substituted with the RCBH revealed a significant difference as compared to that of the cakes substituted with the LCBH $(\mathrm{P}<0.05)$. The TPC content of CBH decreased significantly by LP $(\mathrm{P}<0.05)$. Table 3 shows the data for the TAA of the different PC. One might state that the use of $\mathrm{RCBH}$ as a flour replacement significantly affected the TAC values. Furthermore, cake samples substituted with 
flour which were produced by the LCBH indicated significantly less TAC values $(\mathrm{P}<0.05)$. Similar results were found in other studies in relation to the evaluation of the by-products rich in antioxidants (Dall'Asta et al., 2013; Hayta et al., 2014). Dall'Asta et al. (2013) added the chestnut flour in bread making and determined the antioxidant capacity of the bread samples $0.73,1.00,1.04$ $\mu \mathrm{mol}$ Troloks/g DM for the control, 20\% and 50\% flour substituted breads, respectively. Hayta et al. (2012) studied on the TPC of grape pomace added breads by replacing the flour with the grape pomace powder in the ratios of $2 \%$, $5 \%, 10 \%$. They reported the TPC of control bread as 35.39 mg GAE/100g DM and 53.42, 67.51, 89.43mg GAE/100g DM for the $2 \%-5 \%-10 \%$ bread samples. The phenolic and antioxidant contents of the cakes containing $\mathrm{CBH}$ produced in the study were found to be higher than the bakery products produced with some other food byproducts such as chestnut and grape pomace substituted breads. The TPC contents of the bread fortified with CBH were higher than those of Hayta et al. (2012). However, that was due to the addition levels of $\mathrm{CBH}$ were higher than of Hayta et al. (2012). Sęczyk et al. (2017) investigated the fortification of bread by the addition of the flaxseed hulls. In this study, it was stated the TPC, the free radical scavenging activity and the reducing power in the breads enriched with the flaxseed hull significantly higher than the control bread. From the point of view of the physical properties, one might conclude that the hardness of the bread was increasing with the addition of hulls while the bread volume was decreasing significantly $(\mathrm{P}<0.05)$.

\section{Physical Characteristics of PC}

Table 3 shows the specific volume decreased by the increment in the ratio of the $\mathrm{CBH}$ added into the cakes $(\mathrm{P}>0.05)$. Based on the interaction of gluten and fiber, expression of gas cells has been limited by expansion, resulting in the decline of the cake volume (Dhingra and Jood, 2004). Thus, the specific volume of PC was reduced as the fiber content of the cake formulation rose. The baking loss fell down by the addition of the $\mathrm{CBH}$ in the cake samples. These issues were determined as statistically significant among the control sample, 20RCBH and $20 \mathrm{LCBH}(\mathrm{P}<0.05)$. These results were in agreement with those obtained by Belghith-Fendri et al. (2016) who reported that the specific volume and baking loss of the cakes decreased in the wheat flour fortified with pea pod and broad bean pod powder at the levels of 5-10-15-20-25$30 \%$ when compared to those of the control cakes. The color parameters of CR and CB are reported in Table 4.

Table 3. Chemical compositions and physical characteristics of cakes

\begin{tabular}{cc|cccccccc}
\hline CS & CHR & M & A & P & CF & TPC & TAA & SV & BL \\
\hline Control & 0 & $29.26 \pm 0.35^{\mathrm{b}}$ & $2.29 \pm 0.16^{\mathrm{a}}$ & $8.14 \pm 0.17^{\mathrm{b}}$ & $0.55 \pm 0.39^{\mathrm{a}}$ & $17.34 \pm 0.82^{\mathrm{a}}$ & $0.70 \pm 0.02^{\mathrm{a}}$ & $2.16 \pm 0.20^{\mathrm{a}}$ & $7.29 \pm 0.34^{\mathrm{b}}$ \\
\hline \multirow{3}{*}{$\mathrm{RCBH}$} & 20 & $26.78 \pm 0.84^{\mathrm{a}, \mathrm{b}}$ & $2.64 \pm 0.12^{\mathrm{a}, \mathrm{b}}$ & $7.45 \pm 0.07^{\mathrm{a}}$ & $1.82 \pm 0.05^{\mathrm{b}}$ & $72.73 \pm 4.15^{\mathrm{b}, \mathrm{c}}$ & $3.04 \pm 0.07^{\mathrm{c}}$ & $2.11 \pm 0.10^{\mathrm{a}}$ & $5.95 \pm 0.27^{\mathrm{a}}$ \\
& 30 & $26.31 \pm 0.27^{\mathrm{a}}$ & $2.52 \pm 0.21^{\mathrm{a}, \mathrm{b}}$ & $7.55 \pm 0.05^{\mathrm{a}}$ & $2.00 \pm 0.75^{\mathrm{b}}$ & $91.94 \pm 0.02^{\mathrm{d}}$ & $4.22 \pm 0.41^{\mathrm{d}}$ & $2.09 \pm 0.06^{\mathrm{a}}$ & $6.64 \pm 0.66^{\mathrm{a}, \mathrm{b}}$ \\
& 40 & $25.98 \pm 0.43^{\mathrm{a}}$ & $2.80 \pm 0.21^{\mathrm{b}}$ & $7.56 \pm 0.27^{\mathrm{a}}$ & $3.85 \pm 0.10^{\mathrm{d}}$ & $107.79 \pm 1.22^{\mathrm{e}}$ & $4.74 \pm 0.71^{\mathrm{d}}$ & $2.08 \pm 0.04^{\mathrm{a}}$ & $6.82 \pm 0.37^{\mathrm{a}, \mathrm{b}}$ \\
\hline \multirow{3}{*}{$\mathrm{LCBH}$} & 20 & $26.80 \pm 1.43^{\mathrm{a}, \mathrm{b}}$ & $2.48 \pm 0.17^{\mathrm{a}, \mathrm{b}}$ & $7.62 \pm 0.18^{\mathrm{a}}$ & $2.22 \pm 0.04^{\mathrm{b}, \mathrm{c}}$ & $67.98 \pm 7.24^{\mathrm{b}}$ & $0.70 \pm 0.02^{\mathrm{a}}$ & $2.01 \pm 0.04^{\mathrm{a}}$ & $6.06 \pm 0.18^{\mathrm{a}}$ \\
& 30 & $27.74 \pm 0.19^{\mathrm{b}}$ & $2.75 \pm 0.26^{\mathrm{b}}$ & $7.71 \pm 0.41^{\mathrm{a}}$ & $3.12 \pm 0.39^{\mathrm{c}, \mathrm{d}}$ & $75.77 \pm 8.48^{\mathrm{c}}$ & $1.48 \pm 0.98^{\mathrm{b}}$ & $1.99 \pm 0.08^{\mathrm{a}}$ & $6.85 \pm 0.29^{\mathrm{a}, \mathrm{b}}$ \\
& 40 & $26.05 \pm 0.87^{\mathrm{a}}$ & $3.38 \pm 0.43^{\mathrm{c}}$ & $8.25 \pm 0.36^{\mathrm{b}}$ & $4.90 \pm 0.44^{\mathrm{e}}$ & $79.08 \pm 3.89^{\mathrm{c}}$ & $1.50 \pm 0.18^{\mathrm{b}}$ & $2.03 \pm 0.03^{\mathrm{a}}$ & $6.93 \pm 0.51^{\mathrm{a}, \mathrm{b}}$ \\
\hline
\end{tabular}

CS: Cake samples, CHR: Cocoa hull ratios (\%), M: Moisture (g/100g), A: Ash (g/100g dm*), P: Protein (g/100g dm), CF: Crude fiber (g/100g dm), TPC: Total phenolic compounds (mg GAE**/100 g dm), TAA: Total antioxidant activity ( $\mu$ mol Troloks/g dm), SV: Specific volume (cm $3 / \mathrm{g}$ ), BL: Baking loss $(\%)$, Means \pm standard deviation followed by different letters within a column for each cultivar are significantly different at $\mathrm{P}<0.05$, $* \mathrm{dm}=$ dry matter, $* * \mathrm{GAE}=$ gallic acid equivalent

Table 4. Colour and texture properties of cakes

\begin{tabular}{|c|c|c|c|c|c|c|c|}
\hline \multirow{2}{*}{ CS } & \multirow{2}{*}{$\mathrm{CH}$} & \multicolumn{3}{|c|}{ Crust } & \multicolumn{3}{|c|}{ Crumb } \\
\hline & & $L^{*}$ & $a^{*}$ & $b^{*}$ & $L^{*}$ & $a^{*}$ & $b^{*}$ \\
\hline Control & 0 & $47.10 \pm 1.40^{c}$ & $13.58 \pm 1.25^{\mathrm{e}}$ & $15.76 \pm 3.57^{c}$ & $70.76 \pm 1.20^{\mathrm{e}}$ & $-0.85 \pm 0.35^{\mathrm{a}}$ & $22.40 \pm 0.54^{\mathrm{e}}$ \\
\hline \multirow{3}{*}{$\mathrm{RCBH}$} & 20 & $36.13 \pm 1.91^{b}$ & $9.10 \pm 0.44^{\mathrm{d}}$ & $6.12 \pm 1.19^{\mathrm{b}}$ & $33.39 \pm 1.77^{\mathrm{d}}$ & $8.37 \pm 0.24^{\mathrm{g}}$ & $6.34 \pm 0.52^{\mathrm{d}}$ \\
\hline & 30 & $33.41 \pm 2.34^{\mathrm{a}}$ & $7.36 \pm 0.31^{\mathrm{c}}$ & $2.83 \pm 0.77^{\mathrm{a}}$ & $30.86 \pm 1.48^{c}$ & $7.77 \pm 0.50^{\mathrm{f}}$ & $3.60 \pm 0.76^{\mathrm{c}}$ \\
\hline & 40 & $33.43 \pm 1.79^{\mathrm{a}}$ & $6.38 \pm 0.44^{\mathrm{b}}$ & $1.67 \pm 0.58^{\mathrm{a}}$ & $29.50 \pm 1.59^{\mathrm{b}, \mathrm{c}}$ & $7.03 \pm 0.51^{\mathrm{e}}$ & $1.83 \pm 0.72^{\mathrm{b}}$ \\
\hline \multirow{3}{*}{$\mathrm{LCBH}$} & 20 & $37.75 \pm 3.63^{b}$ & $7.81 \pm 0.62^{c}$ & $7.68 \pm 1.99^{b}$ & $32.95 \pm 3.57^{\mathrm{d}}$ & $6.19 \pm 0.38^{c}$ & $3.99 \pm 1.17^{\mathrm{c}}$ \\
\hline & 30 & $33.74 \pm 2.38^{\mathrm{a}}$ & $5.50 \pm 0.15^{\mathrm{a}}$ & $2.75 \pm 1.09^{\mathrm{a}}$ & $28.61 \pm 2.61^{\mathrm{a}, \mathrm{b}}$ & $5.50 \pm 0.23^{b}$ & $1.01 \pm 0.63^{\mathrm{a}}$ \\
\hline & 40 & $33.18 \pm 1.76^{\mathrm{a}}$ & $5.21 \pm 0.30^{\mathrm{a}}$ & $2.25 \pm 1.36^{\mathrm{a}}$ & $27.17 \pm 2.28^{a}$ & $5.01 \pm 0.21^{\mathrm{a}}$ & $0.51 \pm 0.40^{\mathrm{a}}$ \\
\hline \multirow{2}{*}{ CS } & \multirow{2}{*}{$\mathrm{CH}$} & \multicolumn{6}{|c|}{ Texture } \\
\hline & & \multicolumn{2}{|c|}{ Hardness $(\mathrm{N})$} & Springiness & \multicolumn{2}{|c|}{ Cohesiveness } & Chewiness (N) \\
\hline \multirow[t]{2}{*}{ Control } & 0 & \multicolumn{2}{|c|}{$11.45 \pm 0.86^{\mathrm{a}}$} & $0.94 \pm 0.02^{b}$ & \multicolumn{2}{|c|}{$0.77 \pm 0.00^{\mathrm{e}}$} & $8.23 \pm 0.55^{\mathrm{a}}$ \\
\hline & 20 & \multicolumn{2}{|c|}{$12.74 \pm 2.57^{\mathrm{a}, \mathrm{b}}$} & $0.91 \pm 0.06^{\mathrm{b}}$ & \multicolumn{2}{|c|}{$0.62 \pm 0.03^{\mathrm{d}}$} & $7.25 \pm 1.93^{\mathrm{a}}$ \\
\hline \multirow[t]{2}{*}{$\mathrm{RCBH}$} & 30 & \multicolumn{2}{|c|}{$15.66 \pm 3.34^{\mathrm{b}, \mathrm{c}}$} & $0.89 \pm 0.04^{\mathrm{b}}$ & \multicolumn{2}{|c|}{$0.56 \pm 0.03^{\mathrm{b}, \mathrm{c}}$} & $7.83 \pm 2.03^{\mathrm{a}, \mathrm{b}}$ \\
\hline & 40 & \multicolumn{2}{|c|}{$17.46 \pm 4.09^{\mathrm{c}, \mathrm{d}}$} & $0.83 \pm 0.04^{\mathrm{a}}$ & \multicolumn{2}{|c|}{$0.50 \pm 0.02^{\mathrm{a}}$} & $7.28 \pm 2.11^{\mathrm{a}}$ \\
\hline \multirow{3}{*}{$\mathrm{LCBH}$} & 20 & \multicolumn{2}{|c|}{$14.69 \pm 1.74^{\mathrm{a}, \mathrm{b}, \mathrm{c}}$} & $0.93 \pm 0.02^{b}$ & \multicolumn{2}{|c|}{$0.63 \pm 0.00^{\mathrm{d}}$} & $8.56 \pm 1.03^{\mathrm{a}, \mathrm{b}}$ \\
\hline & 30 & \multirow{2}{*}{\multicolumn{2}{|c|}{$\begin{array}{c}18.65 \pm 1.74^{\mathrm{c}, \mathrm{d}} \\
21.20 \pm 2.40^{\mathrm{d}}\end{array}$}} & $0.88 \pm 0.03^{b}$ & \multirow{2}{*}{\multicolumn{2}{|c|}{$\begin{array}{c}0.58 \pm 0.02^{\mathrm{c}} \\
0.53 \pm 0.03^{\mathrm{a}, \mathrm{b}}\end{array}$}} & \multirow{2}{*}{$\begin{array}{l}9.64 \pm 1.35^{\mathrm{a}, \mathrm{b}} \\
9.90 \pm 1.18^{\mathrm{a}, \mathrm{b}}\end{array}$} \\
\hline & 40 & & & $0.89 \pm 0.03^{b}$ & & & \\
\hline
\end{tabular}

CS: Cake samples, $\mathrm{CH}$ : Cocoa hull ratios (\%), Means \pm standard deviation followed by different letters within a column for each cultivar are significantly different at $\mathrm{P}<0.05$ 
The $L, a$ and $b$ colour values of $\mathrm{CB}$ enriched with $\mathrm{LCBH}$ were less than the ones of the samples enriched with the RCBH. The values for redness and yellowness of $\mathrm{CB}$ decreased by the increase in the ratios of $\mathrm{CBH}$ added into the samples and the values of LCBH were significantly less than those of the $\mathrm{RCBH}$. As a result, the original colour parameter (a value) of $\mathrm{CBH}$ had a darkening effect on the CB. The findings of the previous studies support the addition of food by-products on bakery formulations. It was reported that the colour of the products such as coffee silverskin added to biscuits also influenced their colour (Garcia-Serna et al., 2014). The textural properties of seven cake samples are reported in Table 4.

The $\mathrm{CCH}$ of the control cake was significantly less than the ones of the $30 \%$ and $40 \% \mathrm{RCBH}$ and $\mathrm{LCBH}$ cakes $(\mathrm{P}<0.05)$. Only the cohesiveness fell significantly with the increasing levels of the $\mathrm{CBH}$ added to the samples. In regard to the springiness, only the value of the $40 \mathrm{RCBH}$ was significantly lower than the one of the control sample $(\mathrm{P}<0.05)$. Table 4 illustrated no statistically significant difference among the FSC and control cake with respect of the cake's chewiness $(\mathrm{P}>0.05)$. Dall'Asta et al. (2013) reported the hardness of the bread sample substituted with the $50 \%$ chestnut flour. They revealed that the cohesiveness and chewiness of those samples were significantly higher than the values of the control bread $(\mathrm{P}<0.05)$.

\section{Sensorial Properties of PC}

According to the ranking test, the cakes substituted with the flour were not significantly different $(\mathrm{P}<0.05)$ in terms of taste and overall acceptance. The maximum preferable weight ratio (Overall acceptance) for the $\mathrm{CBH}$ in the cakes was determined $60 \%$. On the other hand, the cakes substituted with the $20 \%, 30 \%$ and $40 \%$ flour ratios showed statistically significant differences in terms of texture and color $(\mathrm{P}>0.05)$. The ranking test results indicated that the formulation would be prepared by the addition of the $\mathrm{CBH}$ up to the ratio of $40 \%$ which would not adversely affect the sensory properties of the cakes.

Figure 1 shows the twelve descriptive properties of the PC. As the amount of cocoa hulls increased in the cake samples, the properties such as crumb brownness, hardness (hand), cocoa taste, bitter taste, and odour were perceived with increasing amounts of cocoa bean in RCBH and LCBH cakes. The differences in the values of cell uniformity, adhesiveness, hardness (mouth), oiliness, moistness, fibrousness, sweetness were found to be insignificant by the panellists $(\mathrm{P}>0.05)$. In terms of the cell uniformity, hardness (hand), adhesiveness, cocoa taste and bitter taste, the cake samples produced with the LCBH had lower scores than the samples to which $\mathrm{CBH}$ was added at the same concentration. In the literature, springiness, cohesiveness, difficulty in chewing and swallowing, bitter taste, chocolate taste, sweetness of soluble cocoa fiber substituted muffins were perceived distinctively (Martinez-Cervera et al., 2011). As it is shown in Figure 2, the clustering analysis and principal component analysis (PCA) were applied using twelve different sensory definitions developed to demonstrate the relationship between FSC. The cluster analysis indicated that there were three basic groups of flour-replacing cakes (Figure $2 \mathrm{~A})$. The first group was composed of $20 \mathrm{RCBH}$ and $20 \mathrm{LCBH}$, the second group consists of $30 \mathrm{RCBH}, 30 \mathrm{LCBH}$ and 40LCBH and the third group include the 40RCBH. In order to determine the effects of the components in the grouping, 5 basic components, namely F1, F2, F3, F4 and F5, which constitute $64.54 \%, 23.61 \%, 6.79 \%, 3.62 \%$, $1.53 \%$ of the total variation in the PCA applied to the samples were obtained respectively. From the biplot diagram drawn by considering the basic components of F1 and F2, cell uniformity, adhesiveness, sweetness, oiliness and humidity values of $20 \mathrm{LCBH}$ and $20 \mathrm{RCBH}$ were distinguishable from those of the other samples. The $30 \mathrm{LCBH}$ and 40LCBH samples differ from the $30 \mathrm{RCBH}$ and 40RCBH samples in terms of hardness (in the mouth), odour, fibrousness, and crumb brownness (Figure 2B). The $40 \mathrm{RCBH}$ differs distinctively from the $30 \mathrm{RCBH}, 30 \mathrm{LCBH}$ and 40LCBH samples in terms of hardness (hand and mouth), cocoa taste, bitter taste, crumb brownness, fibrousness, odor properties being effective (Figure 2B).

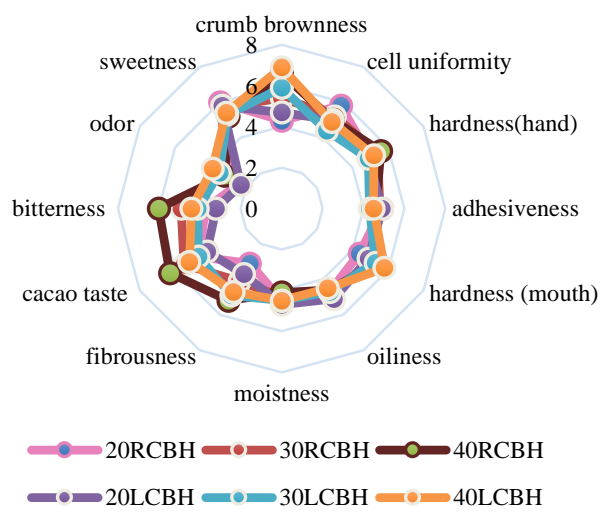

Figure 1. Descriptive sensory analysis of flour substituted cakes

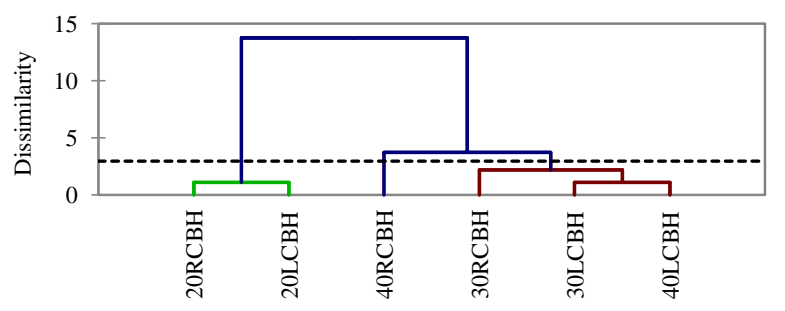

(a)

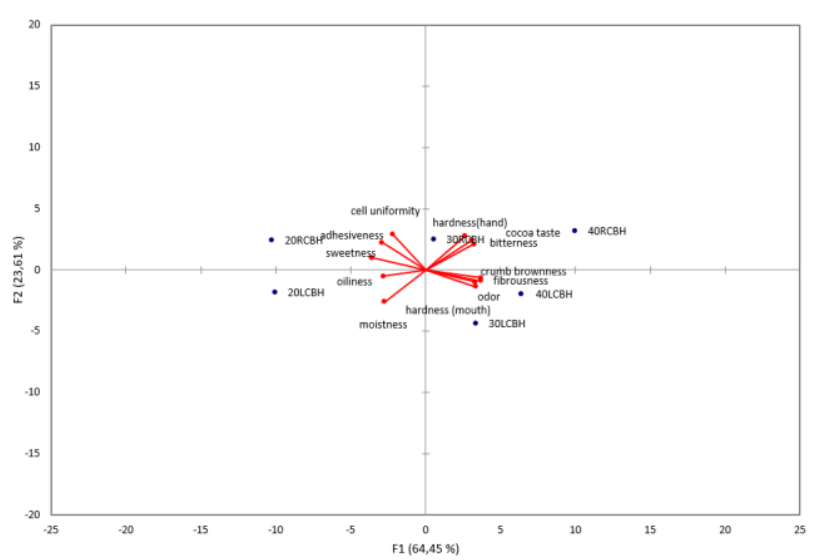

(b)

Figure 2. Principal component analysis of descriptive sensory analysis. (a) Dendogram of cluster analysis. (b) Biplot diagram 


\section{Conclusions}

According to the findings of this research, ash, protein, WRC, WSI, TPC, TFC, TAA, caffeine and theobromine contents of CBH decreased as a result of LP. Therefore, TPC and TAA of the cakes produced from LCBH were found to be less. The cakes produced using flour which included bioactive compounds and crude fiber differed significantly from the control cake. The effects of $\mathrm{CBH}$ on the physical properties of the cakes were evaluated; the baking loss of them decreased with respect to the value of the control cake while the specific volume showed no significant difference. According to the results of the textural analysis of the cakes containing $\mathrm{CBH}$, the greater amount of $\mathrm{CBH}$ present in the samples, the higher hardness of the cake. The results of the descriptive sensorial properties are in accordance with those of the textural properties of the cakes. Consequently, it was determined that the use of the RCBH could be beneficial in terms of the enhancement of the chemical, physical and sensorial properties. Moreover, the 40RCBH could be recommended for the production of functional cakes as the flour substitutes. As a result of this study, the CBH can be evaluated in the development of functional novel foods.

\section{Acknowledgements}

The authors are thankful to Ege University BAP (Scientific Research Projects) for financial support and Ülker Çikolata Sanayi A.Ş. for obtaining CBH.

\section{References}

AACC. 2000. Approved methods of the American Association of Cereal Chemists. St. Paul, MN: American Association of Cereal Chemists.

Açar ÖÇ, Gökmen V, Pellegrini N, Fogliano V. 2009.Direct evaluation of the total antioxidant capacity of raw and roasted pulses, nuts and seeds, European Food Research Technology, 229:961-969.

Adamafio NA.2013. Theobromine Toxicity and Remediation of Cocoa By-products: Overview, Journal of Biological Science, 13(7): 570-576

Alasalvar C,Shahidi F.2008. Tree nuts: Composition, phytochemicals, and health effects, CRC Press Taylor \& Francis Group, Boca Raton, FL: p. 1-10.

Altuğ T. 1987. Tozkakaodatağşişsaptamametodlarıüzerine, PhD. Thesis (Supervisor: Dr. MeralGönül), Ege University Engineering Faculty, Food Engineering Department.: p. 76.

Altuğ T,Elmacı Y. 2015. Duyusaldeğerlendirme. Press SidasMedya Ltd. Şti. Ege University Engineering Faculty, İzmir, TR: p. 127.

AOAC.2007. Official methods of analysis of AOAC International. Washington, DC: Association of Official Analytical Chemists.

Arlorio M, Coìsson JD, Travaglia F, Varsaldi F, Miglio G, Lombardi G, Martelli A. 2005. Antioxidant and biological activity of phenolic pigments from Theobroma cocoa hulls extracted with supercritical CO2, Food Research International, 38:1009 - 1014.

Balestra F, Cocci E, Pinnavaia G, Romani S. 2011. Evaluation of antioxidant, rheological and sensorial properties of wheat flour dough and bread containing ginger powder, LWT - Food Science and Technology, 44(3):700-705.
Belghith-Fendri L, Chaari F, Kallel F, Zouari-Ellouzi S, Ghorbel R, Besbes S, Ellouz-Chaabouni Ghribi-Aydi D. 2016. Pea and Broad Bean Pods as a natural source of dietary fiber: impact on texture and sensory properties of cake, Journal of Food Science, 81 (10).

Bruna C, Eichholz I, Rohn S, Kroh LW, Huyskens - Keil S. 2009. Bioactive compounds and antioxidant activity of cocoa hulls (Theobroma cocoa L.) from different origins, Journal of Applied Botany and Food Quality, 83: 9-13.

Camargo AC, Vidal CMM, Canniatti-Brazaca SG, Shahidi F. 2014. Fortification of Cookies with Peanut Skins: Effects on the Composition, Polyphenols, Antioxidant Properties, and Sensory Quality, Journal of Agricultural Food Chemistry, 62: 11228-11235.

Chang SK, Alasalvar C, Bolling BW, Shahidi F. 2016. Nuts and their co-products: The impact of processing (roasting) on phenolics, bioavailability, and health benefits - A comprehensive review, Journal of Functional Foods, 26:88122.

Chen Z, Zhu C, Zhang Y, Niu D, Du J. 2010. Effects of aqueous chlorine dioxide treatment on enzymatic browning and shelflife of fresh-cut asparagus lettuce (Lactuca sativa L.). Postharvest Biology and Technology, 58(3): 232-238.

Dall'Asta C, Cirlini M, Morini E, Rinaldi M, Ganino T, Chiavaro E. 2013. Effect of chestnut flour supplementation on physicochemical properties and volatiles in bread making, Food Science and Technology, 53(1): 233-239.

Dhingra S, Jood S. 2004. Effect of flour blending on functional, baking and organoleptic characteristics of bread, International Journal of Food Science and Technology, 39: 213-222.

Garcia-Serna E, Martinez-Saez N, Mesias M, Morales JF, Dolores del Castillo M. 2014. Use of Coffee Silverskin and Stevia to Improve the Formulation of Biscuits, Polish Journal of Food and Nutrition Sciences, 64(4): 243-251, http://journal.pan.olsztyn.pl

Hao M, Beta T. 2012. Development of Chinese steamed bread enriched in bioactive compounds from barley hull and flaxseed hull extracts, Food Chemistry, 133: 1320-1325.

Hayta M, Özuğur G, Etgü H, Seker İT. 2014. Effect of Grape (VitisVinifera L.) Pomace Onthe Quality, Total Phenolic Content and Anti-Radical Activity of Bread, Journal of Food Processing and Preservation, 38: 980-986.

Heimler D, Vignolini P, Dinı MG, Vincieri F, Romani A. 2005. Antiradical Activity and Polyphenol Composition of Local Brassicaceae Edible Varieties, Food Chemistry, 82: 15111517.

Johnson DW. 1970. Functional properties of oilseed proteins. Journal of the American Oil Chemists Society, 47(10): 402407.

Kocer D, HicsasmazZ, Bayindirli A, Katnas S. 2007. Bubble and pore formation of the high-ratio cake formulation with polydextrose as a sugar-and fat-replacer, Journal of Food Engineering, 78: 953-964.

Kopp GM, Pearson SM, Shah M. 2011. Process for milling cocoa shells, (ErişimTarihi: 05.02.2017) .

Lecumberri E, Mateos R, Izquierdo-Pulido M, Rupérez P, Goya L, Bravo L. 2007. Dietary fibre composition, antioxidant capacity and physico-chemical properties of a fibre-rich product from cocoa (Theobroma cacao L.), Food Chemistry, 104:948-954.

Martínez R, Torres P, MenesesMA, Figueroa JG, Pérez-Álvarez JA,Viuda-Martos M. 2012. Chemical, technological and in vitro antioxidant properties of cocoa (Theobroma cacao L.) co-products. Food Research International, 49:39-45.

Martínez-Cervera S, Salvador A, Muguerza B, Moulay L, Fiszman SM. 2011. Cocoa fibre and its application as a fat replacer in chocolate muffins, Food Science and Technology, 44:729-736 
Pourfarzad A, Mahdavian- Mehr H, Sedaghat N. 2013. Coffee silverskin as a source of dietary fiber in bread-making: Optimization of chemical treatment using response surface methodology, Food Science and Technology, 50:599 - 606.

Pritchard JLR. 1991. Analysis and Properties of Oilseeds in Analysis of Oilseeds, Fats and Fatty Foods, Eds. Rossel, J.B. and Pritchard, J.L.R., Elsevier Asyflied Science, London and New York.

Rapisarda P, Tomaino A, Cascio R, Bonina F, De Pasquale F, Saija A. 1999. Antioxidant effectiveness as influenced by phenolic content of fresh orange juice. Journal of Agricultural and Food Chemistry, 47:4718-4723.

Robertson JA, De-Monredon FD, Dysseler P, Guillon F, Amado R, Thibault JF. 2000. Hydration properties of dietary fibre and resistant starch: A European collaborative study. LebensmittelWissenschaftTechnologie, 33:72-79.

Rupasinghe HPV, Wang L, Huber GM, Pitts NL. 2008. Effect of baking on dietaryfiber and phenolic of muffins incorporated with apple skin powder, Food Chemistry, 107:1217-1224.
Saija A, Trombetta D, Tomaino A, Lo Cascio R, Princi P, Uccella N, Bonina F, Castelli F. 1998. 'In vitro' evaluation of the antioxidant activity and biomembrane interaction of the plant phenols oleuropein and hydroxytyrosol, International Journal of Pharmaceutics, 166:123-133.

Sęczyk Ł, Świeca M, Dziki D, Anders A, Gawlik-Dziki U. 2017. Antioxidant, nutritional and functional characteristics of wheat bread enriched with ground flaxseed hulls, Food Chemistry, 214:32-38.

Skerget M, Kotnik P, Hadolin M, Hras AR, Simonic M,Knez Z. 2005. Phenols, proanthocyanidins, flavones and flavonols in some plant materials and their antioxidant activities, Food Chemistry, 89:191-198.

Timbie DJ, Sechrist L, Kenney PG. 1978. Application of HPLC to the study of variables affecting theobromine and caffeine concentrations in cocoa beans. Journalof Food Science,43:560-562.

Yang J, Xiao A, Wang C. 2014. Novel development and characterization of dietary fiber from yellow soybean hulls, Food Chemistry, 161:367-375. 